\title{
Peningkatan Kemampuan Operasi Hitung Penjumlahan dan Pengurangan Dengan Media Konkret Pada Siswa Kelas 1 SD Negeri Bantarkawung 03
}

\author{
Alif Rizkiana \\ SDN Bantarkawung 03 \\ rizkianaalif76@gmail.com
}

\section{Article History}

received 3/12/2020

revised $17 / 12 / 2020$

accepted 31/12/2020

\begin{abstract}
The arithmetic operations of addition and subtraction are basic mathematics that must be learned since the 1st grade of elementary school to make it easier for students to do mathematics in advanced grades. In this research, the aim is to improve the ability to do arithmetic operations of addition and subtraction with concrete media for grade 1 students at SD Negeri Bantarkawung 03. Through classroom action research, the quality of learning can be improved because the teacher immediately knows what needs to be improved. The number of respondents studied in this study were all first grade elementary school students, totaling 22 students. This research was carried out in 2 cycles. Based on the description of the implementation of the action, the results of the research and discussion, data were obtained that there was an increase in the ability to do arithmetic addition and subtraction operations in each cycle. It can be seen from the application of the pre-cycle, that is, $40 \%$ has increased to $20 \%$, so the total is $60 \%$ in the first cycle, then it has increased in the second cycle, which is an increase of $27 \%$, the total increase is $87 \%$. The conclusion is that using concrete objects media can improve the ability of addition and subtraction arithmetic operations in grade 1 students of SD Negeri Bantarkawung 03.
\end{abstract}

Keywords: arithmetic operations, concrete media

\begin{abstract}
Abstrak
Operasi hitung penjumlahan dan pengurangan adalah matematika dasar yang harus dipelajari sejak kelas 1 SD untuk mempermudah siswa mengerjakan matematika di kelas lanjutan. Dalam penelitian ini tujuanya adalah untuk meningkatkan kemampuan mengerjakan operasi hitung penjumlahan dan pengurangan dengan media konkret siswa kelas 1 SD Negeri Bantarkawung 03. Melalui penelitian tindakan kelas, kualitas pembelajaran dapat ditingkatkan karena guru langsung mengetahui apa yang harus diperbaiki. Jumlah responden yang diteliti dalam penelitian ini adalah semua siswa kelas 1 SD yang berjumlah 22 siswa. Penelitian ini dilaksanakn dengan 2 siklus. Berdasarkan deskripsi pelaksanaan tindakan, hasil pretest dan pos test dan pembahasan, diperoleh data adanya peningkatan kemampuan mengerjakan operasi hitung penjumlahan dan pengurangan dalam setiap siklus. Dapat dilihat dari penerapan pra siklus yaitu $40 \%$ mengalami peningkatan menjadi $20 \%$ jadi totalnya $60 \%$ pada siklus pertama kemudian mengalami peningkatan pada siklus ke 2 yaitu meningkat sebanyak $27 \%$ total peningkatan adalah $87 \%$. Simpulan dengan menggunakan media benda konkret dapat meningkatkan kemampuan operasi hitung penjumlahan dan pengurangan pada siswa kelas 1 SD Negeri Bantarkawung 03.
\end{abstract}

Kata kunci: Operasi hitung, media konkret,

Social, Humanities, and Education Studies (SHEs): Conference Series https://jurnal.uns.ac.id/shes

p-ISSN 2620-9284 e-ISSN 2620-9292 


\section{PENDAHULUAN}

Pentingnya Operasi hitung penjumlahan dan pengurangan pada siswa kelas 1 SD adalah sebagai modal awal untuk melanjutkan pada jenjang sekolah yang lebih tinggi. Matematika adalah salah satu pelajaran yang ada di sekolah dan dinilai memegang peranan yang sangat penting karena matematika dapat meningktakan pengetahuan siswa dalam berpikir secara logis, rasional, kritis, cermat, efektif dan efisien. Dalam hal ini matematika adalah pelajaran yang bersifat hierarki maka setiap sub bab yang ada dalam matematika akan saling berhubungan dengan sub bab befikutnya. Maka dari itu siswa kelas 1 SD sedari dini harus sudah benar-benar mampu menguasai matematika terutama dalam menghitung operasi hitung penjumlahan dan pengurangan sebagai dasar awal dalam mempelajari tentang ilmu matematika dan kedepannya.

Dalam kenyataanya di lapangan yang terjadi sekarang ini berkaitan dengan hasil belajar siswa kelas 1 SD mengenai operasi hitung penjumlahan dan pengurangan terlihat kurang begitu maksimal. Hal ini dapat dilihat saat proses pembelajaran yang berlangsung siswa kelas 1 SD terlihat kurang semangat, bosan, tidak fokus, pasif dan tidak mendengarkan penjelasan guru. Terlihat bukti dari 22 siswa hanya ada 40\% siswa yang mampu mengerjakan soal operasi hitung penjumlahan dan pengurangan dengan benar. Disini kita melihat bahwa pemeblajaran yang digunakan oleh guru terutama metode yang digunakan hanya menggunakan ceramah, tanya jawab dan pemberian tugas saja. Guru tidak memperhatikan penggunaan media untuk menarik motivasi belajar siswa terutama dalam mengerjakan soal penjumalahan dan pengurangan.

Agar motivasi belajar siswa meningkat, guru harus memperhatikan karakter siswa untuk menentukan media, model, pendekatan dan metode yang yang tepat digunakan saat pembelajaran. Siswa kelas 1 Sekolah dasar masih berada dalam fase operasional konkret,maka dari itu disini penggunaan media konkrit sangat mendukung proses pembelajaran saat menjelaskan tentang menghitung penjumlahan dan pengurangan. Penggunaan media terutama media konkret dapat lebih dimaknai oleh siswa. Bab V pasal 12 UU RI No. 14 tahun 2005 tentang guru dan dosen menjelaskan bahwa siswa mendapatkan pelayanan pendidikan sesuai bakat, minat dan kemampuanya.

Guru berusaha menyediakan media pembelajaran untuk memenuhi pelayanan terhadpa siswa-siswinya. Media berasl dari kata medium yang berarti perantara. Oleh karen itu secara harfiah media diartikan sebagai perantara atau pengantar pesan. Association for Educational Communicatios and Technology (AECT,1994), yang bergerak dalam bidang teknoligi komunikasi dan pendidikan mendefinisikan media adalah "segala bentuk yang digunakan untuk menyalurkan informasi". Menurut Heinich dan Molenda (dalam Drs. Ngalim Purwanto, MP, 2000:1) mengemukakan secara umum bahwa media adalah alat komunikasi yang membawa pesan dari sumber ke penerima. Kesimpulannya bahwa media adalah segala sesuatu yang dapat menjadi perantara dengan maksud memberikan penjelasan dari sumber kepada perantara.

Menurut Ibrahim dan Nana Syaodih (2003), menyatakan bahwa "media benda konkret adalah objek yang sesungguhnya yang akan memberikan rangsangan yang amat penting bagi siswa dalam mempelajari berbagai hal, terutama yang menyangkut pengembangan keterampilan tertentu."Pengertian media benda konkret juga dapat diartikan alat peraga seperti yang dikemukakan oleh Subari (1994), bahwa "alat peraga adalah alat yang digunakan oleh pengajar untuk mewujudkan atau mendemonstrasikan bahan pengajaran guna memberikan pengertian atau gambaran yang sangat jelas tentang pelajaran yang diberikan.

Penggunaan media benda konkret dalam pembelajaran dijadikan sebagai solusi dalam mengatasi masalah yang ada di SD Negeri Bantarkawung 03 dalam mengajarkan operasi hitung penjumalahan dan pengurangan. Karena seperti yang 
telah dipaparkan sebelumnya mengenai tahap perkembangan anak usia sekolah dasar yakni masih dalam tahap operasional konkret, dimana anak usia sekolah dasar masih memerlukan media yang nyata untuk lebih menumbuhkan pemahaman konsep yang matang. Media adalah alat yang dapat membantu proses belajar mengajar yang berfungsi memperjelas makna pesan yang disampaikan sehingga tujuan pengajaran dapat tercapai dengan sempurna. Secara umum kegiatan belajar mengajar di sekolah harus menyenangkan, mencerdaskan, dan menguatkan daya fikir siswa yang berpedoman pada tujuan pembelajaran, sehingga kegiatan belajar mengajar akan lebih efektif. Melalui pemakaian media/alat peraga, imajinasi anak dirangsang, perasaannya disentuh dan kesan yang mendalam diperoleh. Melaluinya anak belajar dengan semangat dan dapat mengingat dengan baik.

Sehubungan dengan penggunaan media dalam kegiatan pembelajaran, para tenaga pengajar atau guru perlu cermat dalam pemilihan dan atau penetapan media yang akan digunakannya. Kecermatan dan ketepatan dalam pemilihan media akan menunjang efektivitas kegiatan pembelajaran yang dilakukannya. Penggunaan media benda konkret dalam pembelajaran operasi hitung penjumlahan dan pengurangan siswa akan semakin tertarik dan termotivasi dalam belajar. Siswa akan semakin aktif dan meningkat kemampuannya dalam meghitung oprasi penjumlahan dan pengurangan. Berdasarkan dari latar belakang tersebut maka penulis mencoba melakukan penelitian yang berjudul : "Peningkatan Kemampuan Operasi Hitung Penjumlahan dan Pengurangan Dengan Media Konkret Pada Siswa Kelas 1 SD Negeri Bantarkawung 03". Tujuan Khusus dari penelitian ini adalah Meningkatkan kemampuan siswa dalam mengerjakan penjumlahan dan pengurangan pada pelajaran matematika kelas 1 SD N Bantarkawung 03.

\section{METODE}

Penelitian ini adalah penelitian kualitatif dan kuantitatif. Data kuantatif berupa nilai hasil belajar siswa dengan rentang nilai 0 sampai 100 . Nilai tersebut diperoleh dari hasil tes formatif yang dikerjakan siswa pada setiap siklus. Nilai hasil belajar siswa selanjutnya dirata-rata untuk menemukan rata-rata keberhasilan siswa secara klasikal. Data kualitatif berupa deskripsi hasil observasi terhadap aktivitas siswa pada saat melaksanakan pembelajaran, selain itu data kualitatif berupa lembar observasi pelaksanaan pembelajaran yang dilaksanakan dengan menerapkan media konkret dalam proses pembelajaran. Tehnik pengumpulan data dalam PTK ini dilaksanakan dengan dua cara pretest dan post tes. Pretest dilaksanakan untuk mengukur tingkat kemampuan mengerjakan operasi hitung penjumlahan dan pengurangan siswa dalam pembelajaran matematika awal. Post tes dilaksanakan dengan menggunakan lembar tes yang dilaksanakan dengan mengerjakan soal pembelajaran siswa dengan media konkret dalam pembelajaran operasi hitung penjumlahan dan pengurangan.

Alat pengumpulan data dalam PTK yang dilaksanakan adalah butir-butir soal dan lembar observasi. Pengecekan keabsahan data dilakukan dengan memadukan hasil observasi, hasil-hasil catatan dari pengamat beserta evaluasi yang dilakukan untuk menjaga keabsahan data perlu dilakukan diskusi-diskusi dengan pengamat sehingga kesimpulan yang diperoleh sangat tepat sesuai. Melalui PTK ini dalam menggunakan media konkret kemampuan siswa dalam mengerjakan operasi hitung penjumlahan dan pengurangan di harapkan akan mengalami peningkatan. Siswa lebih aktif dalam pembelajaran dan guru lebih bervariasi dalam menggunakan media pembelajaran. Penelitian ini berhasil apabila kemampuan siswa dalam mengerjakan operasi hitung penjumlahan dan pengurangan meningkat $60 \%$ pada siklus 1, dan $80 \%$ pada siklus 2 . Kinerja guru dalam penerapan media konkret ternyata meningkat dari $60 \%$ pada siklus 1 meningkat menjadi $87 \%$ pada siklus 2 . 


\section{HASIL DAN PEMBAHASAN}

Pada siklus I pembelajaran dilaksanakan selama dua pertemuan, setiap pertemuan diadakan pre test dan post test. Untuk mengetahui perkembangan peserta didik selama pembelajaran. Siklus I melakukan pembelajaran menghitung operasi penjumalahan dan pengurangan menggunakan buku guru dan buku siswa. Dalam tahap ini penulis mengajak siswa untuk belajar menghitung penjumlahan dan pengurangan dengan cara konvensional tanpa menggunakan media konkret hanya menggunakan metode ceramah dengan buku guru dan buku siswa

Tabel 1. Hasil Belajar Siswa Kelas 1 SD N Bantarkawung 03 Siklus I

\begin{tabular}{|c|c|c|c|c|c|c|c|c|}
\hline \multirow{3}{*}{ SIKLUS I } & \multicolumn{4}{|c|}{ PRETEST } & \multicolumn{4}{|c|}{ POST TEST } \\
\hline & \multicolumn{2}{|c|}{$\begin{array}{l}\text { SISWA } \\
\text { TUNTAS }\end{array}$} & \multicolumn{2}{|c|}{$\begin{array}{l}\text { SISWA } \\
\text { BELUM } \\
\text { TUNTAS }\end{array}$} & \multicolumn{2}{|c|}{$\begin{array}{l}\text { SISWA } \\
\text { TUNTAS }\end{array}$} & \multicolumn{2}{|c|}{$\begin{array}{c}\text { SISWA } \\
\text { BELUM } \\
\text { TUNTAS }\end{array}$} \\
\hline & JML & $\%$ & JML & $\%$ & JML & $\%$ & JML & $\%$ \\
\hline $\begin{array}{c}\text { PERTEMUAN } \\
1\end{array}$ & 9 & 40 & 13 & 60 & 10 & 48 & 12 & 52 \\
\hline $\begin{array}{c}\text { PERTEMUAN } \\
2\end{array}$ & 10 & 48 & 12 & 52 & 13 & 60 & 9 & 40 \\
\hline
\end{tabular}

Berdasarkan tabel di atas maka terjadi peningkatan antara pre test dan post test pada pertemuan 1. Setiap individu peserta didik sudah mengalami peningkatan hasil belajarnya. Peserta didik mengalami peningkatan hasil belajar pada pertemuan 1. Ketuntasan klasikal juga mengalami peningkatan, pada pre test hanya terdapat 7 siswa yang sudah tuntas, tetapi pada post test bertambah menjadi 9 siswa yang sudah tuntas dengan Kriteria Ketuntasan Minimal (KKM) sebesar 70. Demikian juga pada pertemuan 2 jumlah siswa yang sudah tuntas KKM mengalami peningkatan. Pada pre test ada 9 anak yang baru tuntas, sudah meningkat menjadi 14 siswa yang tuntas setelah melaksanakan post test. Perbandingan antara hasil post test pada pertemuan 1 dan pertemuan 2 juga terdapat perbedaan. Pada pertemuan 1 siswa yang sudah tuntas hanya ada 9 siswa, sedangkan pada pertemuan 2 sudah meningkat menjadi 13 siswa. Persentase ketuntasan klasikalnya meningkat, jika pertemuan 1 hanya $40 \%$ maka pada pertemuan 2 menjadi $60 \%$.

Berdasarkan refleksi pada siklus I maka diputuskan untuk melanjutkan ke siklus II dikarenakan belum mencapai ketuntasan yang diharapkan. Siklus II membahas materi tentang operasi hitung penjumlahan dan pengurangan. Pembelajaran dengan menggunakan media konkret. Berikut ini adalah hasil belajar siswa kelas 1 SD $\mathrm{N}$ Batarkawung 03 pada siklus II yang bisa dilihat pada tabel berikut.

Tabel 2. Hasil Belajar Siswa kelas 1 SD N Bantarkawung 03 Siklus II

\begin{tabular}{|c|c|c|c|c|c|c|c|c|}
\hline \multirow{3}{*}{ SIKLUS I } & \multicolumn{4}{|c|}{ PRETEST } & \multicolumn{4}{|c|}{ POST TEST } \\
\hline & \multicolumn{2}{|c|}{$\begin{array}{c}\text { SISWA } \\
\text { TUNTAS }\end{array}$} & \multicolumn{2}{|c|}{$\begin{array}{l}\text { SISWA } \\
\text { BELUM } \\
\text { TUNTAS }\end{array}$} & \multicolumn{2}{|c|}{$\begin{array}{c}\text { SISWA } \\
\text { TUNTAS }\end{array}$} & \multicolumn{2}{|c|}{$\begin{array}{c}\text { SISWA } \\
\text { BELUM } \\
\text { TUNTAS }\end{array}$} \\
\hline & JML & $\%$ & JML & $\%$ & JML & $\%$ & JML & $\%$ \\
\hline $\begin{array}{c}\text { PERTEMUAN } \\
1\end{array}$ & 13 & 60 & 9 & 40 & 16 & 72 & 6 & 28 \\
\hline $\begin{array}{c}\text { PERTEMUAN } \\
2\end{array}$ & 16 & 72 & 6 & 28 & 19 & 87 & 3 & 16 \\
\hline
\end{tabular}

Berdasarkan tabel di atas maka terjadi peningkatan antara pre test dan post test pada pertemuan 1. Setiap siswa sudah mengalami peningkatan hasil belajarnya. 
Ketuntasan klasikal juga mengalami peningkatan, pada pre test hanya terdapat 13 siswa yang sudah tuntas, tetapi pada post test bertambah menjadi 16 siswa yang sudah tuntas dengan Kriteria Ketuntasan Minimal (KKM) sebesar 70. Demikian juga pada pertemuan 2 jumlah siswa yang sudah tuntas KKM mengalami peningkatan. Pada pre test ada 16 siswa yang baru tuntas, sudah meningkat menjadi 19 siswa yang tuntas setelah melaksanakan post test. Perbandingan antara hasil post test pada pertemuan 1 dan pertemuan 2 juga terdapat perbedaan. Pada pertemuan 1 siswa yang sudah tuntas hanya ada 13 siswa, sedangkan pada pertemuan 2 sudah meningkat menjadi 19 siswa. Persentase ketuntasan klasikalnya meningkat, jika pertemuan 1 hanya $60 \%$ maka pada pertemuan 2 menjadi $87 \%$.

Kegiatan pembelajaran dalam upaya untuk meningkatkan kemampuan belajar siswa kelas $1 \mathrm{SD}$ dalam proses penjumlahan dan pengurangan bilangan sangat dibutuhkan media yang konkret. Menurut Sri Anitah (2009) "media dapat diartikan sebagai perantara atau penghubung antara dua pihak, yaitu antara sumber pesan dengan penerima. Siswa Kelas 1 tidak akan berhasil dalam pembelajaran apabila hanya menghafal konsep. Perlu diingat bahwa siswa Kelas 1 masih identik dengan dunia bermain dan sangat memerlukan media yang nyata untuk dapat memahami konsep. Jadi alangkah baiknya bila dalam proses pembelajarannya juga menggunakan media nyata yaitu media kongkret.

Sebelum penelitian tindakan kelas dilaksanakan peneliti dibantu beberapa guru melakukan Observasi lapangan sebagai tindakan awal. Kegiatan ini dilakukan untuk mengetahui seberapa besar tingkat ketuntasan belajar siswa dalam melakukan operasi penjumlahan dan pengurangan bilangan dalam pembelajaran Matematika. Dari kegiatan Observasi awal ini diperoleh data kemampuan siswa dalam mengerjakan hitung penjumlahan dan pengurangan masih rendah,hal ini disebabkan karena pada proses pembelajaran guru masih menggunakan metode konvensional.

Dari data tersebut dapat disimpulkan bahwa operasi penjumlahan dan pengurangan bilangan belum berhasil. Kemudian peneliti mencoba untuk meningkatkan kemampuan siswa dalam mengerjakan penjumlahan dan pengurangan bilangan dengan menggunakan media konkret karena melalui media yang nyata dapat meningkatkan kemampuan siswa dalam mengerjakan hitung. Hal ini sesuai dengan teori Bruner bahwa dalam proses belajar anak diberi kesempatan untuk memanipulasi benda atau alat peraga dan mengotak-atik alat peraga sehingga siswa akan memahami suatu konsep matematika. Oleh karena itu, guru hendaknya memanfaatkan media dalam proses belajar mengajar sehingga merangsang siswa untuk belajar dan mengoptimalkan intelektual siswa. Setelah dilakukan penelitan tindakan kelas peneliti mengambil evaluasi dari masing-masing siklus dengan tujuan untuk mengetahui ada tidaknya peningkatan kemampuan siswa.

Berdasarkan observasi dengan kriteria yang sudah ditetapkan pada siklus I kemampuan siswa dalam mengerjakan operasi hitung penjumlahan dan pengurangan pada pra siklus $40 \%$ meningkat $20 \%$ menjadi $60 \%$ dan meningkat pada siklus II sebanyak $27 \%$ yaitu mencapai $87 \%$. Peningkatan kemampuan siswa dalam mengerjakan operasi hitung penjumlahan dan pengurangan dapat dilihat pada tabel dibawah ini.

Tabel 3. Peningkatan Kemampuan Siswa Dalam Operasi Hitung

\begin{tabular}{ccc}
\hline Pra Siklus & Siklus 1 & Siklus 2 \\
$40 \%$ & $60 \%$ & $87 \%$ \\
\hline
\end{tabular}

Dengan penggunaan media konkret siswa terlibat langsung dalam proses belajar mengajar, siswa dapat memanipulasi media sehingga siswa berperan aktif dalam 
pembelajaran untuk memahami konsep matematika dan mengembangkan keterampilan intelektualnya. Hal ini sesuai dengan teori Bruner bahwa dalam proses belajar anak diberi kesempatan untuk memanipulasi benda atau alat peraga dan mengotak-atik alat peraga sehingga siswa akan memahami suatu konsep matematika. Oleh karena itu, guru hendaknya memanfaatkan media dalam proses belajar mengajar sehingga merangsang siswa untuk belajar dan mengoptimalkan intelektual siswa.

Dari data kemampuan siswa dalam mengerjakan hitung penjumlahan dan pengurangan dan data penerapan media konkret, dapat dinyatakan bahwa melalui penggunaan media konkret dapat meningkatkan kemampuan mengerjakan operasi hitung pada pembelajaran matematika materi penjumlahan dan pengurangan di kelas I SD Negeri Bantarkawung 03 semester 1 tahun pelajaran 2019/2020.

\section{SIMPULAN}

Awal pembelajaran yang metode yang digunakan adalah metode konvensioanal dan menggunakan media buku ajar dan buku siswa. Setelah diadakan pra siklus ternyata kemampuan menghitung operasional penjumalahan dan pengurangan siswa masih rendah. Dengan mendengarkan ceramah dari guru, tanya jawab dan pemberian tugas pada siswa, keadaan seperti ini siswa menjadi bosan dan kurang termotivasi dalam belajar. Peneliti berusaha untuk memperbaiki pembelajaran dengan menggunakan media konkret untuk meningkatkan Kemampuan siswa dalam mengerjakan hitung penjumlahan dan pengurangan diSDN Bantarkawung 03. Berdasarkan deskripsi pelaksanaan tindakan, hasil penelitian, dan pembahasan, diperoleh data adanya peningkatan kemampuan mengerjakan hitung dalam setiap siklus. Kemampuan pada pra siklus $40 \%$ meningkat $20 \%$ menjadi $60 \%$ pd siklus I dan meningkat pada siklus II sebanyak $27 \%$ yaitu mencapai $87 \%$.

Penggunaan media konkret dapat menarik perhatian siswa, memperjelas pemahaman konsep penjumlahan dan pengurangan dan membuat siswa aktif dalam pembelajaran. Adanya aktifitas pembelajaran yang meningkat, suasana pembelajaran yang menyenangkan sehingga akhirnya kemampuan mengerjakan penjumlahan dan pengurangan pada siswa kelas 1 SD Negeri Bantarkawung 03 meningkat.

\section{DAFTAR PUSTAKA}

Ariyanto.2011.Pembelajaran Aritmatika Sekolah Dasar. Solobaru:Qinant

Affi Rahma Khaerani, dkk. 2019. Media Belajar Inovatif, Kreatif dan Asyik. Banyumas: CV Rizqunaa

Departemen Pendidikan Nasional. 2005. Undang-Undang Republik Indonesia, Nomor 14 Tahun 2005 Tentang Guru dan Dosen. Citra Umbara : Bandung.

Dimyati dan Mudjiono. 2002. Belajar dan Pembelajaran. Jakarta: Rineka Cipta.

Drs. H. Abu Ahmadi dan Drs. Widodo Supriyono.2004.Psikologi Belajar.Jakarta: Rineka Cipta

Ibrahim dan Nana Syaodih. 2003.Perencanaan Pengajaran. Jakarta: Rineka Cipta

Joko Suwandi.2011.Penelitian Tindakan Kelas.Solobaru: Qinant

M. Toha Anggoro, dkk.2007.Metode Penelitian. Jakarta: Universitas Terbuka 2007. Tim Penyusun Kamus Pusat Bahasa. 2002. Kamus Besar Bahasa Indonesia. Jakarta: BaLai Pustaka

Mulyono. 2003. Pendidikan Bagi Anak Berkesulitan Belajar. Jakarta: Depdikbud dan Rineka Cipta. 